\title{
Visfatin affects redox adaptative responses and proliferation in Me45 human malignant melanoma cells: An in vitro study
}

\author{
RAFA JAKUB BUŁDAK ${ }^{1}$, ŁUKASZ BUŁDAK ${ }^{3}$, RENATA POLANIAK ${ }^{3}$, \\ MICHAŁ KUKLA ${ }^{1}$, EWA BIRKNER ${ }^{2}$, ROBERT KUBINA ${ }^{4}$, AGATA KABAŁA-DZIK ${ }^{4}$, \\ ANNA DUŁAWA-BUŁDAK ${ }^{3}$ and KRYSTYNAŻWIRSKA-KORCZALA ${ }^{1}$ \\ Departments of ${ }^{1}$ Physiology and ${ }^{2}$ General Biochemistry, Medical University of Silesia, Zabrze; \\ ${ }^{3}$ Department of Internal Medicine and Clinical Pharmacology, Medical University of Silesia, \\ Katowice; ${ }^{4}$ Department of Pathology, Medical University of Silesia, Sosnowiec, Poland
}

Received September 6, 2012; Accepted October 18, 2012

DOI: $10.3892 /$ or.2012.2175

\begin{abstract}
Visfatin has recently been established as a novel adipokine that is predominantly expressed in subcutaneous and visceral fat. Only few studies have investigated the effect of visfatin on prostate, breast, ovarian cancer as well as on astrocytoma cell biology. There have been no previous studies on antioxidative enzyme activities, proliferation processes or levels of DNA damage in malignant melanoma cells in response to visfatin stimulation. Here, we report that visfatin increases activity of selected antioxidative enzymes (SOD, CAT, GSH-Px) in culture supernatants of Me45 human malignant melanoma cells. Our findings suggest that visfatin triggers a redox adaptation response, leading to an upregulation of antioxidant capacity along with decreased levels of the lipid peroxidation process in Me45 melanoma cells. Moreover, visfatin led to a significantly increased proliferation rate in the study using the $\left[{ }^{3} \mathrm{H}\right]$ thymidine incorporation method. Unlike insulin, visfatin-induced melanoma cell proliferation is not mediated by an insulin receptor. Better understanding of the role of visfatin in melanoma redox states may provide sound insight into the association between obesity-related fat adipokines and the antioxidant defense system in vitro in melanoma progression.
\end{abstract}

\section{Introduction}

A critical area of obesity research is centered on circulating proteins, the levels of which are altered by changes in the body mass index. Understanding how these proteins affect obesity-associated diseases may provide invaluable clues to constrain the devastating consequences of the current obesity

Correspondence to: Dr Rafał Jakub Bułdak, Department of Physiology, Medical University of Silesia, 19 Jordana Street, 41-808 Zabrze, Poland

E-mail: rbuldak@sum.edu.pl

Key words: visfatin, adipocytokines, antioxidant enzymes, lipid peroxidation process, DNA damage, proliferation, melanoma epidemic (1). One such protein, visfatin/eNampt/PBEF, has recently received much attention, but its biological effects and mechanisms of action are not well understood. Obesity is the risk factor of breast (2), endometrial (3) and hepatocellular cancer (4), as well as skin melanoma (5). It has been reported that visfatin augments oxidative stress in differentiated myotubes (6) and endothelial cells (7). Nevertheless, the causal relationship between these facts remains unclear. Visfatin is a novel fat derived adipocytokine, secreted by visceral and subcutaneous fat tissues $(8,9)$, hepatocytes $(10)$, monocytes and macrophages (11-13). Visfatin has both intra- and extracellular forms in mammals $(14,15)$. An extracellular form of this protein has been reported to act as a cytokine known as visfatin/PBEF (16), an insulin-mimetic hormone (17), or an extracellular NAD biosynthetic enzyme, visfatin/eNampt (18). Only few studies have investigated the effect of visfatin on cancer cells in vitro and in vivo. Increased expression of visfatin was confirmed in ovarian cancer (19); malignant astrocytoma (20); the human prostate cancer cell lines, $\mathrm{LNCaP}$ (androgen-sensitive) and PC3 (androgen-insensitive); as well as in human prostate cancer (21).

Reactive oxygen metabolites (ROMs), such as superoxide anions $\left(\mathrm{O}_{2}{ }^{*}\right)$ hydrogen peroxide $\left(\mathrm{H}_{2} \mathrm{O}_{2}\right)$, and hydroxyl radical $\left(\mathrm{OH}^{*}\right)$, malondialdehyde (MDA) and nitric oxide (NO) are directly or indirectly involved in the multistage process of carcinogenesis (22). They are mainly involved in DNA damage leading to mutations in tumor suppressor genes. They also act as initiators and/or promoters in carcinogenesis (23). MDA, a by-product of lipid peroxidation is likely involved in DNA adduct formations and DNA damage which are believed to also be responsible for carcinogenesis (24). To counteract ROS-induced DNA damage, cells have developed defensive mechanisms that prevent or repair such damage (25). Antioxidant enzyme systems belong to those regulatory mechanisms whose role is to protect against oxidative stress. Under oxidative stress, ROS are rapidly eliminated by antioxidant enzymes, such as superoxide dismutase (SOD), catalase (CAT) and glutathione peroxidase (GSH-Px) (26).

No studies exploring the effects of adipokines (such as visfatin) on oxidative stress, DNA damage in melanoma cells have been conducted so far. This topic is of utmost interest 
owing to the potential paracrine interactions between subcutaneous adipose tissue and cancer cells. A better understanding of the role of visfatin in melanoma redox states in vitro may provide sound insight into the association between obesityrelated fat adipokines and the antioxidant defense system in vitro in cancer progression.

\section{Materials and methods}

Cell culture and reagents. A human malignant melanoma Me45 cell line was obtained from the Silesian University of Technology, as a kind gift from Dr M. Wideł from the Marie Curie Memorial Cancer Centre and Institute of Oncology, Gliwice, Poland. The cells were derived from metastatic lesions (local lymph nodes) of a 35-year-old patient of the Institute of Oncology (27). Me45 cells were plated at the density of $1 \times 10^{6}$ cells per $25 \mathrm{~cm}^{2}$ flask and cultured in the Dulbecco's modified Eagle's medium with L-glutamine (Sigma-Aldrich, St. Louis, MO, USA) supplemented with $15 \%$ fetal bovine serum (Gibco, North Androver, MA, USA), antibiotics: penicillin $(10,000 \mathrm{IU} / \mathrm{ml})$, streptomycin $(10,000 \mu \mathrm{g} / \mathrm{ml})$, amphotericin B $(2.5 \mu \mathrm{g} / \mathrm{ml})$ (Sigma-Aldrich) under the atmosphere of $95 \%$ air and $5 \% \mathrm{CO}_{2}$ at $37^{\circ} \mathrm{C}$. The Me45 cell line was free of mycoplasma, pathogenic viruses and bacteria. Cultures were maintained for no longer than 4 weeks after recovery from the frozen stock.

Visfatin (Alexis Biochemical, Plymouth, PA, USA) was dissolved in phosphate buffered saline (PBS) without $\mathrm{Mg}^{2+}$, $\mathrm{Ca}^{2+}$ (Sigma-Aldrich). The visfatin solutions were prepared fresh, protected from light, and added to the incubation medium obtaining the following final concentrations: 10, 50, 100 and $250 \mathrm{ng} / \mathrm{ml}$. The purity of visfatin was 96-97\% (SDS-PAGE analysis) and contained $<0.01 \mathrm{ng} / \mu \mathrm{g}$ LPS as determined by the Limulus amebocyte lysate method.

Hydroxy-2-naphthalenylmethylphosphonic acid trisacetoxymethyl ester [HNMPA-(AM) $)_{3}$, and insulin were also obtained from Sigma Chemicals Co.

Enzyme assay. After exposure of the cultured cells to visfatin for $24 \mathrm{~h}$, antioxidative enzyme activities: MnSOD, $\mathrm{Cu} / \mathrm{ZnSOD}$, GSH-Px, CAT, and the level of malondialdehyde (MDA) were measured in cell supernatants. Cells were collected after $24 \mathrm{~h}$ of incubation with different doses of visfatin $(10-250 \mathrm{ng} / \mathrm{ml})$ and were centrifuged $(2,000 \mathrm{rpm}, 5 \mathrm{~min})$ and supernatants were kept at $-80^{\circ} \mathrm{C}$ until analysis. All experiments were carried out in duplicate. Sample size in all experiments was 12 .

GSH-Px activity assay. The method of Paglia and Valentine, (28) was used with minor modifications. Briefly, Me45 melanoma cells were pooled to a concentration of $5 \times 10^{6}$ cells $/ \mu 1$. Following centrifugation, the cell pellet was mixed with cell lysis buffer and then sonicated for $10 \mathrm{sec}$. The protein concentration was measured using Bio-Rad protein reagent (Bio-Rad Laboratories, Hercules, CA, USA). Equal volumes of each sample containing $30 \mu \mathrm{g}$ of protein were mixed with $2.68 \mathrm{ml}$ of $0.05 \mathrm{M}$ phosphate buffer ( $\mathrm{pH} 7.0$ ) containing $0.005 \mathrm{M}$ ethylenediaminetetraacetic acid (EDTA). The following solutions were then added sequentially: $0.100 \mathrm{ml}$ of $0.0084 \mathrm{M}$ NADPH, 0.010 $\mathrm{ml}$ of glutathione reductase (GR), $0.010 \mathrm{ml}$ of $1.125 \mathrm{M}$ sodium nitrate $\left(\mathrm{NaNO}_{3}\right)$, and $0.100 \mathrm{ml}$ of $0.15 \mathrm{M}$ reduced glutathione
(GSH). The enzymatic reaction was initiated by the addition of $0.100 \mathrm{ml}$ of $0.0022 \mathrm{M} \mathrm{H}_{2} \mathrm{O}_{2}$. The conversion of NADPH to oxidized $\mathrm{NADP}^{+}$was followed by continuous recording of the change in absorbency at $340 \mathrm{~nm}$ between 2 and $4 \mathrm{~min}$ after the initiation of the reaction. The control measurements were recorded in a simultaneous assay where the sample was replaced by an equal volume of cell lysis buffer. GSH-Px enzyme activity (1 IU) is defined as $1 \mathrm{mM}$ NADPH converted to $\mathrm{NADP}^{+}$per mg of protein (IU/mg p).

SOD activity assay. The SOD activity assay was based on a minor modification of the procedure described by Paoletti and Mocali (29). The preparation of cell lysates and the measurement of protein concentration were the same as in the GSH-Px assay. Protein $(30 \mu \mathrm{g})$ from each sample was mixed with $0.8 \mathrm{ml}$ of $1 \mathrm{X}$ triethanolamine-diethanolamine buffer (TDB); ( $\mathrm{pH} 7.4$ ), $40 \mu \mathrm{l}$ of $7.5 \mathrm{mM}$ NADPH (a reduced form of nicotinamide adenine dinucleotide phosphate), and $25 \mu \mathrm{l}$ of $100 \mathrm{mM}$ EDTA$\mathrm{MnCl}_{2}$. The reaction was initiated by the addition of $0.1 \mathrm{ml}$ of $10 \mathrm{mM}$ mercaptoethanol. The decrease in absorbance at $340 \mathrm{~nm}$ was recorded over $20 \mathrm{~min}$ at room temperature. The control consisted of a reaction mixture in which the sample was replaced by an equal volume of cell lysis buffer. For the determination of MnSOD activity, CuZnSOD activity was inhibited by incubating samples with $5 \mathrm{mM}$ potassium cyanide $(\mathrm{KCN})$ for 30 min with samples assayed for activity within $2 \mathrm{~h}$ of adding cyanide to the sample mixture. Total specific SOD and MnSOD (after $\mathrm{CuZnSOD}$ inhibition with $\mathrm{KCN}$ ) activity levels were measured, and then the CuZnSOD activity was calculated. The enzymatic activity of both SOD isoenzymes was expressed in nitric units (NU) per mg of protein (NU/mg p); 1 NU represents $50 \%$ inhibition by SOD of the nitrosol ion formation under these conditions.

CAT activity. Catalase activity was measured spectrophotometrically as described by Aebi (30). Direct disappearance of $10 \mathrm{mM}$ hydrogen peroxide in $50 \mathrm{mM}$ potassium phosphate buffer (pH 7.0), $1 \mathrm{mM}$ EDTA was measured at $240 \mathrm{~nm}>30 \mathrm{sec}$ on a Beckman DU-70 spectrophotometer. Enzyme activity was calculated based on the molar extinction coefficient of hydrogen peroxide at $240 \mathrm{~nm}\left(\varepsilon=39.4 \mathrm{M}^{-1} \mathrm{~cm}^{-1}\right)$ and reported as $\mu \mathrm{mol}$ hydrogen peroxide decomposed per minute, recalculated to $\mathrm{kIU}$ per mg of protein (kIU/mg p).

MDA assay. The measurement of MDA, a product of lipid peroxidation, was determined by the thiobarbituric acid (TBA) reaction as described by Placer et al (31). Aliquots of reaction buffer $(1.5 \mathrm{ml})$ that included $50 \mu \mathrm{g}$ of protein from each sample and $1.4 \mathrm{ml}$ of $0.2 \mathrm{M}$ Tris- $0.16 \mathrm{M} \mathrm{KCl}(\mathrm{pH} 7.4)$ were incubated at $37^{\circ} \mathrm{C}$ for $30 \mathrm{~min}$. Next, $1.5 \mathrm{ml}$ of TBA reagent were added, and the mixture was heated in a boiling water bath for $10 \mathrm{~min}$. After cooling with ice, $3.0 \mathrm{ml}$ of pyridine: $n$-butanol $(3: 1, \mathrm{v} / \mathrm{v})$ and $1.0 \mathrm{ml}$ of $1 \mathrm{M} \mathrm{NaOH}$ were added and mixed by shaking, and the absorbance was read at $548 \mathrm{~nm}$. The blank control contained the same reaction mixture but was not incubated. The level of MDA was expressed as $\mu$ mol MDA per mg of protein $(\mu \mathrm{mol} \mathrm{MDA} / \mathrm{mg} \mathrm{p})$.

Alkaline comet assay. All chemicals were purchased from Sigma. The comet assay was carried out under alkaline condi- 
tions, as described by Olive and Banáth (32). Fully frosted slides were covered with $1 \%$ normal melting point agarose (NMP agarose). Me45 cells $\left(6 \times 10^{3}\right)$, and the same number of cells pretreated with visfatin at the concentration of $100 \mathrm{ng} / \mathrm{ml}$ for $24 \mathrm{~h}$ were washed twice, trypsinized and resuspended in $2 \mathrm{ml}$ fresh medium. Half of the cells from each group were treated for 5 min with $\mathrm{H}_{2} \mathrm{O}_{2}(100 \mu \mathrm{M})$, and the genotoxic factor was removed by centrifugation $(2,000 \mathrm{rpm} / 3 \mathrm{~min})$ with supernatants. Subsequently, cells were resuspended in $2 \mathrm{ml}$ medium and incubated for $0 \mathrm{~min}$ (control for determination of the basal DNA damage) or 5, 15, 30, 60, 120 and $180 \mathrm{~min}$ (for determination of the residual DNA damage). The resuspended cells (50 $\mu \mathrm{l})$ were mixed with $100 \mu \mathrm{l} 0.5 \%$ low melting agarose at $37^{\circ} \mathrm{C}$ and transferred $(100 \mu \mathrm{l})$ onto microscope slides. The cells not treated with $\mathrm{H}_{2} \mathrm{O}_{2}$ were collected at similar time-points.

The slides were immersed for $1 \mathrm{~h}$ in the ice-cold, freshly prepared lysis solution $\left(2.5 \mathrm{M} \mathrm{NaCl}, 100 \mathrm{mM} \mathrm{Na}{ }_{2}\right.$ EDTA, $10 \mathrm{mM}$ Tris- $\mathrm{HCl}, \mathrm{pH} 10.0$ ) with $1 \%$ Triton $\mathrm{X}-100$ and $1 \%$ dimethylsulfoxide added fresh for cell destruction and DNA unfolding. The slides were then randomly placed side by side in the horizontal gel-electrophoresis tank, facing the anode. The unit was filled with freshly prepared electrophoretic buffer ( $300 \mathrm{mM} \mathrm{NaOH}, 1 \mathrm{mM} \mathrm{Na}{ }_{2}$ EDTA, pH 13.0) and the slides were set in this alkaline buffer for $15 \mathrm{~min}$ to allow DNA to unwind and express alkali-labile sites. Denaturation and electrophoresis were performed at $4^{\circ} \mathrm{C}$ under dim light. Electrophoresis was carried out for $20 \mathrm{~min}$ at $25 \mathrm{~V}(300 \mathrm{~mA})$. Following electrophoresis, the slides were washed gently $2 \mathrm{x}$ at 5-min intervals with the neutralization buffer $(0.4 \mathrm{M}$ Tris-HCl, $\mathrm{pH} 7.5)$ to remove excess alkali and detergents. Slides were fixed in chilled $70 \%$ ethanol and stained with ethidium bromide $(20 \mu \mathrm{g} / \mathrm{ml})$ and coverslipped. Slides were stored at $4^{\circ} \mathrm{C}$ in humidified sealed containers. To prevent additional DNA damage, handling samples and preparation of the slides for the comet assay were conducted under yellow light or in the dark. To avoid possible position effects during electrophoresis, two parallel replicate slides per sample were prepared. Each replicate was processed in a different electrophoretic run.

The Comet images were visualized after ethidium bromide staining $(20 \mu \mathrm{g} / \mathrm{ml})$ using a fluorescent microscope (Axiophot M1, Zeiss, Jena, Germany) that was fitted with an excitation filter of 515-535 nm and a barrier filter of $590 \mathrm{~nm}$ at x40 magnification. The Comet images were captured using an online charge-coupled device (CCD) camera and analyzed using the Comet Score software (version 5.5) from Andor Technology (Belfast, UK). The tail moments were quantified for a minimum of 100 random cells per sample using the Comet Score software. The tail moment is defined as the ratio of DNA in the comet tail to total DNA.

Assessment of cell proliferation. Me45 cell proliferation was assessed using scintillation counting to measure the incorporation of $\left[{ }^{3} \mathrm{H}\right]$ thymidine $(2 \mu \mathrm{Ci} / \mathrm{ml})$ into trichloroacetic acid (TCA)-insoluble material. Cells were plated at $2 \times 10^{4} /$ well in 24-well plates and treated with $10-250 \mathrm{ng} / \mathrm{ml}$ visfatin or insulin $(100 \mathrm{ng} / \mathrm{ml})$ for $24 \mathrm{~h}$. To study the effects of insulin receptor (IR) inhibition, HNMPA-(AM) $)_{3}(50 \mu \mathrm{M})$ was added $3 \mathrm{~h}$ before visfatin or insulin, in the presence of $\left[{ }^{3} \mathrm{H}\right]$ thymidine. After $24 \mathrm{~h}$, the plates were washed with PBS and $10 \%$
TCA was added to the wells. Incorporated $\left[{ }^{3} \mathrm{H}\right]$ thymidine was released by washing with $0.2 \mathrm{~N}$ of $\mathrm{NaOH}$, and radioactivity was measured using $\beta$-scintillation counter (Wallac 1410, Pharmacia, Freiburg, Germany). Results were shown as counts per minute. To determine visfatin's effect on the cell number, melanoma cells were plated into 96 -well plates at $2 \times 10^{3} /$ well and treated with $10-250 \mathrm{ng} / \mathrm{ml}$ visfatin or $100 \mathrm{ng} / \mathrm{ml}$ insulin for $24 \mathrm{~h}$. Cells were harvested by trypsinization, and the viable ones were counted in an automated cell counter (model no. TC10; Bio-Rad Laboratories) using 0.04\% trypan blue.

Statistical analysis. The normality of distribution was evaluated by means of Shapiro-Wilk's test. All results are presented as the means \pm SD or a median (IQR). Results underwent statistical analysis, applying the one-way ANOVA test with the Bonferroni's post hoc test or Kruskal-Wallis with Mann-Whitney U test, according to parameter distribution. For repeated measures a Friedman test with Schaich and Hamerle post hoc procedure was used in comet assay data. $\mathrm{P}<0.05$ was considered to indicate statistically significant differences.

\section{Results}

Influence of visfatin on selected antioxidative enzyme activities as well as malondialdehyde level in human malignant melanoma Me45 cells. Visfatin treatment resulted in an increase in antioxidative enzyme activities SOD: (MnSOD, CuZnSOD isoenzymes) and CAT, GSH-Px compared to the control group.

SOD isoenzyme assay. SOD isoenzyme activities (MnSOD, CuZnSOD) after $24 \mathrm{~h}$ of incubation with different concentrations of visfatin are shown in Fig. 1. These experimental groups also showed a statistically significant increase of the activities of both isoenzymes, in relation to the control group. The highest MnSOD isoenzyme activity was observed in the group treated with visfatin at a 100 and $250 \mathrm{ng} / \mathrm{ml}$ concentration compared to the control group $(6.22 \pm 0.55,6.29 \pm 0.34$ vs. $3.42 \pm 0.34 \mathrm{NU} / \mathrm{mg}$ p; $\mathrm{p}<0.001$ ); (Fig. 1A). The MnSOD activity in the two other groups treated with visfatin remained unaltered. All concentrations of visfatin led to a significant 2-fold increase of copper and zinc containing superoxide dismutase isoenzyme $(\mathrm{Cu} / \mathrm{ZnSOD})$ activity when compared to the untreated group; $(3.42 \pm 0.363 .43 \pm 0.523 .52 \pm 0.75,4.01 \pm 0.90$ vs. $1.43 \pm 0.49 \mathrm{NU} / \mathrm{mg}$ $\mathrm{p} ; \mathrm{p}<0.001$ ); (Fig. 1B) The dose-dependency in influencing $\mathrm{CuZnSOD}$ by various visfatin concentrations was not observed.

CAT assay. In comparison to controls, a significant increase in catalase (CAT) activity in all experimental groups was found at $24 \mathrm{~h}$. CAT activity was 2 -and 2.5-fold higher in the group stimulated with visfatin at 10 and $50 \mathrm{ng} / \mathrm{ml}$ than in the control group $(17.96 \pm 1.66,19.12 \pm 1.50$ vs. $7.55 \pm 1.37 \mathrm{kIU} / \mathrm{mg}$ p; $\mathrm{p}<0.001$, respectively). Moreover, a 4-fold increase in the CAT activity was observed in the group treated with visfatin at a concentration of 100 and $250 \mathrm{ng} / \mathrm{ml}$ with respect to the control group; $(32.1 \pm 2.83,35.66 \pm 2.51$ vs. $7.55 \pm 1.37 \mathrm{kIU} / \mathrm{mg}$; $\mathrm{p}<0.001$; respectively) (Fig. 2A).

GSH-Px assay. GSH-Px activity was $\sim 2$-fold higher in the groups treated with visfatin at 50 and $100 \mathrm{ng} / \mathrm{ml}$ compared to the control group $(190.9 \pm 31.6,197.1 \pm 20.3$ vs. $93.51 \pm 6.1 \mathrm{IU} / \mathrm{mg}$; 
A.



B.

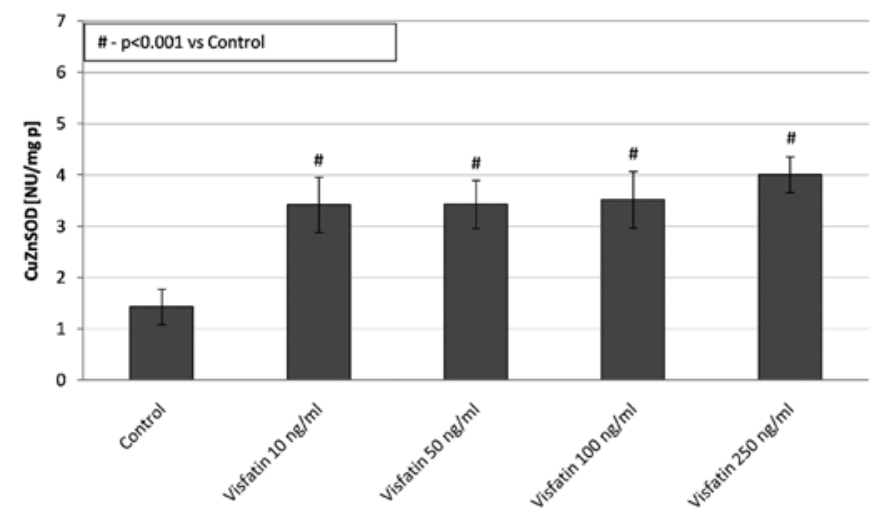

Figure 1. (A) Manganese-dependent (MnSOD) and (B) copper and zinc containing (CuZnSOD) superoxide dismutase activity expressed in NU/mg of protein in the cell supernatants of the human malignant melanoma Me45 cell line upon visfatin stimulation. Data represent the means $\pm S D ; n=12$ and were analyzed with the one-way ANOVA test and post hoc Bonferroni correction: ${ }^{\#} \mathrm{p}<0.001$ vs. control, ${ }^{*} \mathrm{p}<0.001$ vs. $10 \mathrm{ng} / \mathrm{ml}$ visfatin, ${ }^{\wedge} \mathrm{p}<0.001$ vs. $50 \mathrm{ng} / \mathrm{ml}$ visfatin, ${ }^{\$} \mathrm{p}<0.001$ vs. $100 \mathrm{ng} / \mathrm{ml}$ visfatin, ${ }^{\circledR} \mathrm{p}<0.001 \mathrm{vs} .250 \mathrm{ng} / \mathrm{ml}$.

${ }^{\circledR} \mathrm{p}<0.001$, respectively). However a significant decrease in GSH-Px activity was observed when cells were treated with visfatin at a $250 \mathrm{ng} / \mathrm{ml}$ concentration $(55.8 \pm 20.03$ vs. 93.51 $\pm 6.1 \mathrm{IU} / \mathrm{mg}$ p; $\mathrm{p}<0.001$; respectively) (Fig. 2B).

MDA assay. We also studied the influence of visfatin on the MDA level in the supernatants of Me45 cells. The MDA level was 2-fold lower in the group stimulated with $100 \mathrm{ng}$ visfatin compared to the untreated group $(0.79 \pm 0.10$ vs. $1.49 \pm 0.17 \mu \mathrm{mol}$ $\mathrm{MDA} / \mathrm{mg} \mathrm{p} ; \mathrm{p}<0.001$, respectively). On the contrary, the MDA concentration was increased in Me 45 cells stimulated by visfatin at a $250 \mathrm{ng} / \mathrm{ml}$ concentration $(1.69 \pm 0.5$ vs. $1.49 \pm 0.17 \mu \mathrm{mol}$ $\mathrm{MDA} / \mathrm{mg}$ p; $\mathrm{p}<0.001$, respectively) (Fig. 2C).

Evaluation of DNA damage. We also examined the effect of visfatin at the concentration of $100 \mathrm{ng} / \mathrm{ml}$ on DNA damage in Me45 cells. The DNA damage after an incubation of these cells with the genotoxic factor $\mathrm{H}_{2} \mathrm{O}_{2}$ was compared with cells pre-incubated with $100 \mathrm{ng} / \mathrm{ml}$ of visfatin $(24 \mathrm{~h})$ and $\mathrm{H}_{2} \mathrm{O}_{2}$ at different time-points (0-180 min). Fig. 3 shows the level of DNA damage at different time-points (0-180 min) after visfatin and $\mathrm{H}_{2} \mathrm{O}_{2}$ treatment, in comparison to the untreated cells and the cells treated separately, only with $\mathrm{H}_{2} \mathrm{O}_{2}$ or
A.

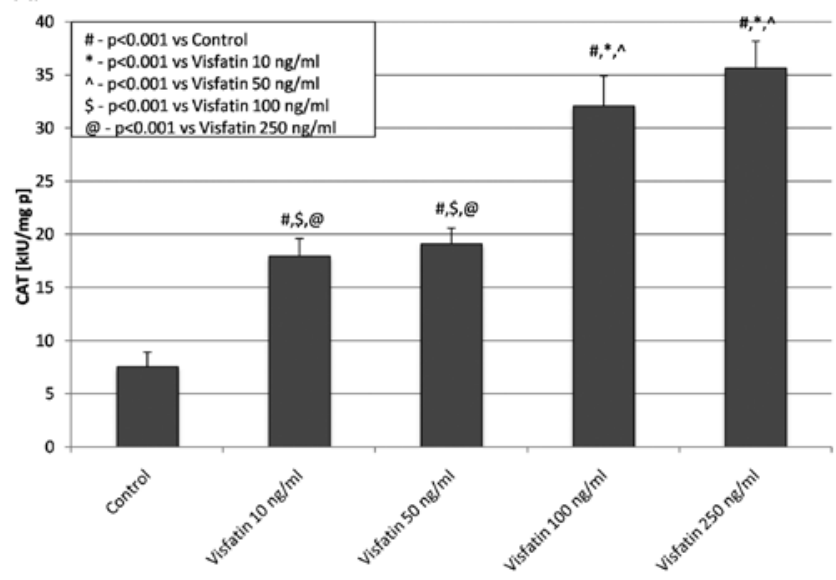

B.

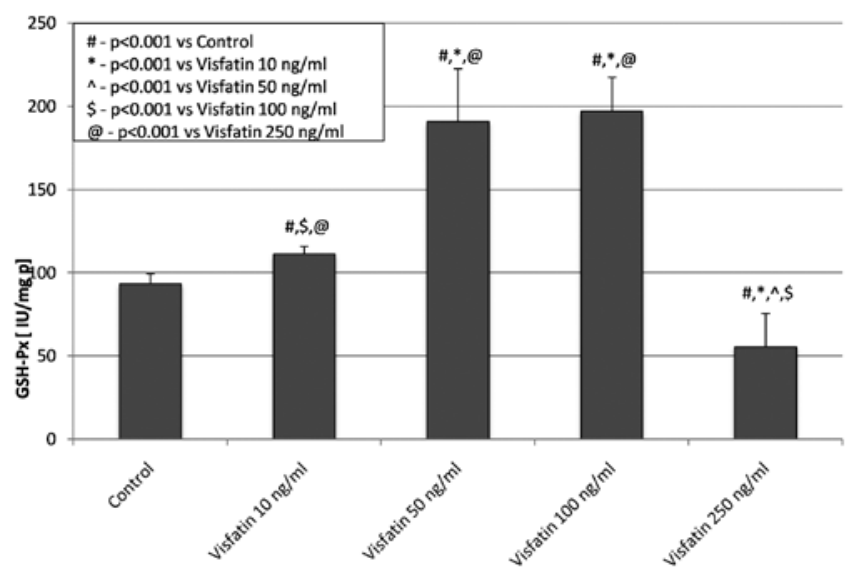

C.

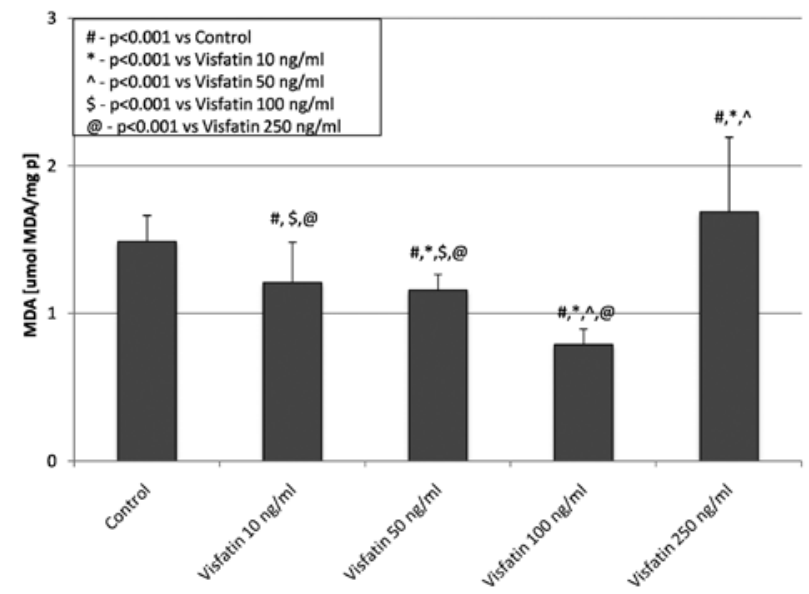

Figure 2. (A) Catalase (CAT); (B) Glutathione peroxidase (GSH-Px) enzyme activities; and (C) malondialdehyde (MDA) levels in the cell supernatants of the human malignant melanoma Me45 cell line upon visfatin stimulation. $\mathrm{C}$, control (untreated) group. Data represent the means $\pm \mathrm{SD} ; \mathrm{n}=12$, and were analyzed with the one-way ANOVA test and post hoc Bonferroni correction [(enzymes activity; ${ }^{*} \mathrm{p}<0.001$ vs. C, ${ }^{*} \mathrm{p}<0.001$ vs. $10 \mathrm{ng} / \mathrm{ml}$ visfatin, ${ }^{\wedge} \mathrm{p}<0.001$ vs. $50 \mathrm{ng} / \mathrm{ml}$ visfatin, ${ }^{\$} \mathrm{p}<0.001$ vs. $100 \mathrm{ng} / \mathrm{ml}$ visfatin, ${ }^{\circledR} \mathrm{p}<0.001$ vs. $250 \mathrm{ng} / \mathrm{ml}$ visfatin); (MDA levels; ${ }^{*} \mathrm{p}<0.001$ vs. $\mathrm{C},{ }^{*} \mathrm{p}<0.001$ vs. $10 \mathrm{ng} / \mathrm{ml}$ visfatin, ${ }^{\wedge} \mathrm{p}<0.001$ vs. $50 \mathrm{ng} / \mathrm{ml},{ }^{\$} \mathrm{p}<0.001$ vs. $100 \mathrm{ng} / \mathrm{ml},{ }^{\oplus} \mathrm{p}<0.05$ vs. $\left.\left.250 \mathrm{ng} / \mathrm{ml}\right)\right]$.

visfatin-control groups. These results are presented as tail length (Fig. 3A) and median tail moment parameter (Fig. 3B) with first and third quartile. In every temporal point after $\mathrm{H}_{2} \mathrm{O}_{2}$ 
A.

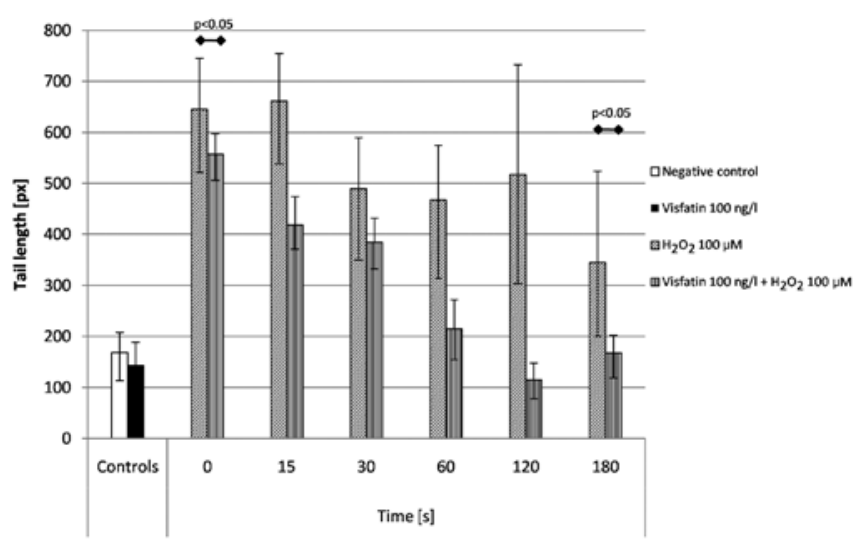

B.



Figure 3. (A) Tail length and (B) tail moment parameter of DNA damage at different time-points $(0-180 \mathrm{~min})$ after hydrogen peroxide $\left(\mathrm{H}_{2} \mathrm{O}_{2}\right)$ removal in the human malignant melanoma Me45 cells pre-incubated with visfatin $(100 \mathrm{ng} / \mathrm{ml})$ for $24 \mathrm{~h}$ and then treated with $\mathrm{H}_{2} \mathrm{O}_{2}(100 \mu \mathrm{M})$ for $5 \mathrm{~min}$ (vertically striped bars) in comparison to the cells exposed solely with hydrogen peroxide (slantwise striped bars) or cells treated with visfatin without adding $\mathrm{H}_{2} \mathrm{O}_{2}$ (black bars). The negative control groups were cells not exposed to hydrogen peroxide and/or visfatin (white bar). Results are shown as a median tail moment expressed in arbitrary units (a.u.) or tail length \pm first quartile $\left(Q_{1}\right)$, third quartile $\left(Q_{3}\right) ; n=100$; Mann-Whitney U test. For repeated measures a Friedman test with the Schaich and Hamerle post hoc procedure was used $(\mathrm{p}<0.05$, respectively).

removal, the DNA damage (expressed as median tail moment or tail length) was decreased in the group treated with visfatin and $\mathrm{H}_{2} \mathrm{O}_{2}$, compared to the group treated solely with $\mathrm{H}_{2} \mathrm{O}_{2}$. Me45 melanoma cells treated with both visfatin and hydrogen peroxide exhibited significantly less DNA damage than the cells treated solely with hydrogen peroxide $(\mathrm{p}<0.05)$. One hundred and eighty minutes after $\mathrm{H}_{2} \mathrm{O}_{2}$ treatment, the DNA damage level in cells treated with both visfatin and $\mathrm{H}_{2} \mathrm{O}_{2}$ was lower than in cells treated solely with $\mathrm{H}_{2} \mathrm{O}_{2}(\mathrm{p}<0.05)$. Addition of visfatin to $\mathrm{H}_{2} \mathrm{O}_{2}$-treated cells resulted in earlier recovery in DNA damage resulting in similar levels of tail moment and tail length $120 \mathrm{~min}$ after removal of $\mathrm{H}_{2} \mathrm{O}_{2}$. The stationary DNA damage (without adding $\mathrm{H}_{2} \mathrm{O}_{2}$ ) was also decreased in the visfatin-treated group when compared to untreated controls (but only in the tail moment parameter of the DNA damage); p $<0.05$ (Fig. 3).
A.

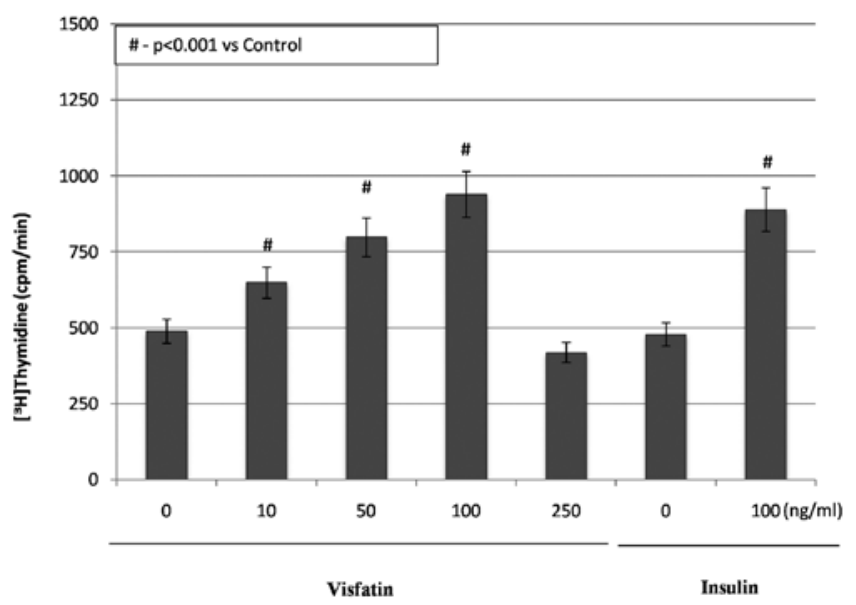

B.

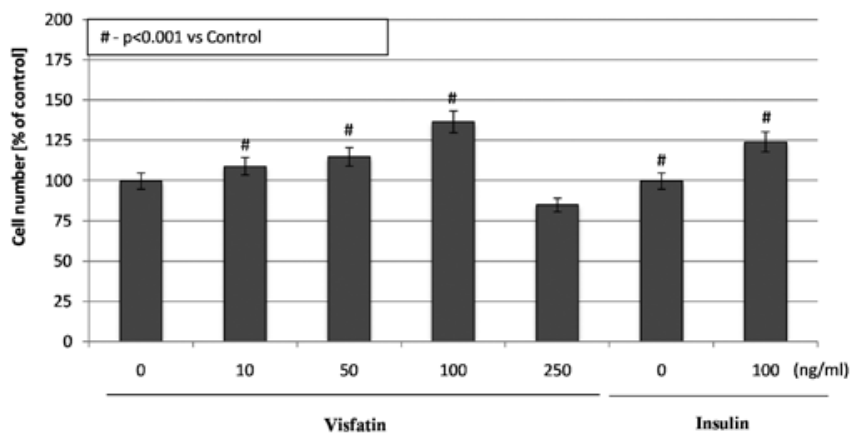

Figure 4. Effects of various concentrations of visfatin or insulin on $\left[{ }^{3} \mathrm{H}\right]$ thymidine incorporation and cell number in human malignant melanoma Me 45 cells. (A) Cells were exposed to $10-250 \mathrm{ng} / \mathrm{ml}$ visfatin or $100 \mathrm{ng} / \mathrm{ml}$ insulin for $24 \mathrm{~h}$. Cell proliferation was determined by measuring $\left[{ }^{3} \mathrm{H}\right]$ thymidine incorporation. Results are expressed as counts per minute. Bars represent means $\pm \operatorname{SD}(n=12)$. ${ }^{\#} \mathrm{p}<0.001$ vs. control (untreated cells). (B) Cells were exposed to $10-250 \mathrm{ng} / \mathrm{ml}$ visfatin or $100 \mathrm{ng} / \mathrm{ml}$ insulin for $24 \mathrm{~h}$. Cell proliferation was determined by cell counts. Results are expressed as the means \pm SD fold increases $(n=12)$ over control values. ${ }^{*} \mathrm{p}<0.001$ vs. control.

Effects of visfatin on the proliferation and viability of Me45 melanoma cells. The measurement of $\left[{ }^{3} \mathrm{H}\right]$ thymidine incorporation showed that visfatin at $10-100 \mathrm{ng} / \mathrm{ml}$ stimulated proliferation of Me45 cells in a dose-dependent manner. Visfatin at the concentration of $250 \mathrm{ng} / \mathrm{ml}$ led to a significant decrease in the proliferation rate of these cells $(15 \%)$ when compared to untreated melanoma cells $(\mathrm{p}<0.05)$ (Fig. 4A). Compared to the control group, visfatin significantly increased $\left[{ }^{3} \mathrm{H}\right]$ thymidine incorporation into melanoma cells by $32.1 \%$ $(10 \mathrm{ng} / \mathrm{ml}), 63 \%(50 \mathrm{ng} / \mathrm{ml})$ and $91.2 \%(100 \mathrm{ng} / \mathrm{ml})(\mathrm{all} \mathrm{p}<0.05)$ (Fig. 4A). Moreover, compared to the control group, visfatin at 10,50 and $100 \mathrm{ng} / \mathrm{ml}$ increased the number of viable melanoma cells by 9,15 and $36.3 \%$, respectively (all $\mathrm{p}<0.05$ ) (Fig. 4B). On the contrary, visfatin at $250 \mathrm{ng} / \mathrm{ml}$ decreased the number of viable melanoma cells by $15 \%$ (Fig. 4B) in comparison to the untreated group $(\mathrm{p}<0.05)$. Fig. 5 shows that insulin also promoted proliferation of Me45 cells. Insulin at $100 \mathrm{ng} / \mathrm{ml}$ markedly increased $\left[{ }^{3} \mathrm{H}\right]$ thymidine incorporation of Me45 cells by $85.4 \%$ with augment number of viable cells 


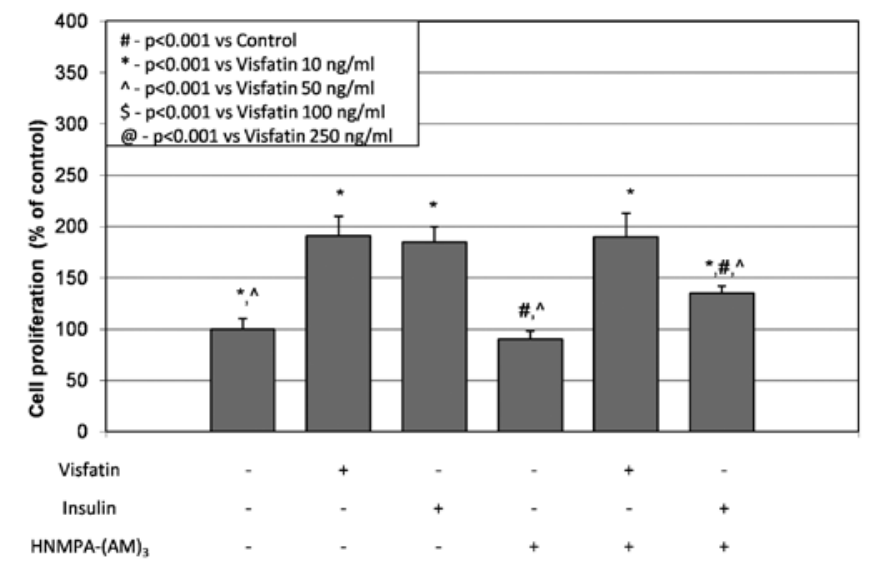

Figure 5. Effects of visfatin or insulin in combination with inhibitor of insulin receptor (HNMPA-AM) $)_{3}$ on the proliferation of human malignant melanoma Me45 cells. Cells were incubated with HNMPA-(AM) $(50 \mu \mathrm{M})$ for $3 \mathrm{~h}$ prior to treatment with $100 \mathrm{ng} / \mathrm{ml}$ visfatin or insulin $100 \mathrm{ng} / \mathrm{ml}$ for 24 h. Cell proliferation was determined using $\left[{ }^{3} \mathrm{H}\right]$ thymidine incorporation. Bars represent the means $\pm \mathrm{SD}(\mathrm{n}=12) ;{ }^{*} \mathrm{p}<0.001$ vs. untreated cells, ${ }^{\#} \mathrm{p}<0.001 \mathrm{vs}$. visfatin-treated control, ${ }^{\mathrm{p}}<0.001$ vs. insulin-treated control.

( $24 \%$ rise vs. untreated cells; $\mathrm{p}<0.05)$. No statistically significant differences between study groups treated with various concentrations of visfatin were observed at the level of $\alpha=0.05$ (excluding visfatin at the concentration of $250 \mathrm{ng} / \mathrm{ml}$ ).

Insulin receptor signaling. Melanoma cells pretreated with the IR tyrosine kinase inhibitor HNMPA-(AM) $)_{3}$ did not show reduced proliferation in visfatin-treated cells (Fig. 5). Additionally, the inhibitor HNMPA-(AM) 3 significantly inhibited insulin-stimulated proliferation of melanoma Me45 cells by $27 \%$ (p<0.05) (Fig. 5). Furthermore, the immunoblot analysis revealed that IR protein expression $(95 \mathrm{kDa})$ could be detected in Me45 melanoma lysates (not shown).

\section{Discussion}

There are no data describing the interactions in subcutaneous microenvironments between adipocytes that secrete various adipokines (such as visfatin) and neighboring melanocytes as well as melanoma cells. This relationship might affect the malignant transformation process of melanocytes. Therefore it seems important to initiate studies that explore the potential paracrine influence of adipokines on melanocytes and melanoma cells.

We studied the role of fat derived-visfatin on antioxidative enzymatic activity and the level of lipid peroxidation process in supernatants of Me45 melanoma cells. In the present study, we observed increased activity of antioxidant enzymes (SOD isoenzymes, catalase and glutathione peroxidase) in cell supernatants upon stimulation with visfatin at the concentration of $10-100 \mathrm{ng} / \mathrm{ml}$. Increased mitochondrial MnSOD isoenzyme activity after visfatin treatment suggests that visfatin increases efficiency of the electron transport chain in the inner mitochondrial membrane and stimulates complex I and IV of the electron transport chain in the mitochondrion (33). Cells subjected to the action of the visfatin at the concentration of $250 \mathrm{ng} / \mathrm{ml}$ for $24 \mathrm{~h}$ showed higher mitochondrial oxidative stress compared to the other group. In our previous study we also observed a marked increase in MnSOD activity after exposure of AT478 tumor cells to extremely low frequency electromagnetic field (ELF-EMF) and vitamin E. This action of ELF-EMF and vitamin $\mathrm{E}$ is expected to increase efficiency of oxidative phosphorylation and adenosine triphosphate production and the high efficiency of ROS elimination by MnSOD itself (34). In this study we also reported increase in $\mathrm{CuZnSOD}$ superoxide dismutase isoenzyme activity in Me45 cells subjected for $24 \mathrm{~h}$ to different concentrations of visfatin.

SOD isoenzymes catalyze the conversion of $\mathrm{O}^{-}$to $\mathrm{H}_{2} \mathrm{O}_{2}$, which can then be converted to water by catalase (CAT) or glutathione peroxidase (GSH-Px) coupled with glutathione reductase (GR) (26). We observed a marked increase in CAT activity in Me45 melanoma cells treated with all concentrations of visfatin. Increased activity of GSH-Px or CAT in cancer cells can make tumor cells less susceptible to anticancer drugs such as doxorubicin $(36,39)$. Samuels et al (35) demonstrated that the addition of radical scavengers and compounds with peroxide activity can reduce the cytotoxic effect of anticancer drugs in vitro. Increased GSH-Px or CAT activity enables cells to survive with the high level of ROS and maintain cellular viability (36).

In our study, application of visfatin (10-100 ng/ml) also decreased the level of lipid peroxidation in Me45 cells with augmented GSH-Px activity. On the contrary, MDA concentration was increased in melanoma cells stimulated by visfatin in higher concentrations and also decreased GSH-Px activity. ROS are known to cause DNA damage and lipid peroxidation/oxidation in cellular membranes (26). MDA is one of the final products of polyunsaturated fatty acid peroxidation in cells. An increase in free radicals causes overproduction of MDA (37). Glutathione peroxidase is an enzyme that reduces hydrogen peroxide as well as organic superoxides. In such reactions, an organic superoxide $(\mathrm{ROOH})$ becomes reduced to an appropriate alcohol $(\mathrm{ROH})$. In the case of lipid superoxide this means that it cannot become an initiator of lipid peroxidation and, therefore, GSH-Px inhibits the lipid peroxidation process $(31,37)$. The results of our experiments with low concentrations of MDA in the group stimulated with $10-100 \mathrm{ng} / \mathrm{ml}$ visfatin is concordant with the high activity of the enzyme inhibiting lipid peroxidation process-glutathione peroxidase (GSH-Px) in this study group when compared to the control group. However, we speculate that the Me45 melanoma cells exposed to visfatin at the concentration of $250 \mathrm{ng} / \mathrm{ml}$ may show decreased resistance toward exogenic $\mathrm{H}_{2} \mathrm{O}_{2}$ and higher oxidative stress in comparison to the cells treated with lower concentrations of visfatin.

We suppose that visfatin at the concentration of $10-100 \mathrm{ng} / \mathrm{ml}$ triggers a redox adaptation response, leading to an upregulation of the antioxidant capacity (SOD isoenzymes, CAT and GSH-Px enzymes).

Moreover, the increased oxidative-stress induces oxidative DNA damage and lipid peroxidation process. We hypothesized that visfatin mediated activation of antioxidant enzymes with decreased levels of MDA may lead to the reduction of DNA damage in Me45 melanoma cells. We pretreated these cells with visfatin at the concentration of $100 \mathrm{ng} / \mathrm{ml}$ for $24 \mathrm{~h}$. At every time-point after $\mathrm{H}_{2} \mathrm{O}_{2}$ removal, the DNA damage (expressed as median tail moment or tail length) was decreased 
in the group treated with visfatin and $\mathrm{H}_{2} \mathrm{O}_{2}$ compared to the group treated solely with $\mathrm{H}_{2} \mathrm{O}_{2}$. The results suggested a protective role of visfatin in the Me45 melanoma cells exposed to the genotoxic reagents. Pretreatment with visfatin before adding hydrogen peroxide decreased DNA damage in the Me45 cells. Our observation of increased antioxidant enzyme activity in melanoma cells after visfatin stimulation shows that enzymatic defense mechanisms are used for ROS scavenging and reduce the level of DNA damage in these cells. Moreover, the stationary DNA damage (without adding $\mathrm{H}_{2} \mathrm{O}_{2}$ ) was also decreased in the visfatin-treated group when compared to the untreated group (but only in tail moment parameter of DNA damage). Collectively, we demonstrated for the first time the protective role of visfatin in hydrogen peroxide-induced DNA damage in a human malignant melanoma cell line. However, Wang et al (38) demonstrated that visfatin exerted anti-apoptotic effects under a cell apoptotic state induced by $\mathrm{H}_{2} \mathrm{O}_{2}$ in vascular smooth muscle cells (38). Moreover, Adya et al (7) reported that visfatin exerted a protective role in $\mathrm{H}_{2} \mathrm{O}_{2}$-induced endothelial cell apoptosis. Visfatin at $100 \mathrm{ng} / \mathrm{ml}$ in combination with $\mathrm{H}_{2} \mathrm{O}_{2}(200 \mu \mathrm{M})$ markedly increased the number of viable cells by $73 \%$ in comparison to the group treated solely with hydrogen peroxide (only $19 \%$ of viable endothelial cells in the culture) (7). This is consistent with our report, which demonstrates that visfatin at $100 \mathrm{ng} / \mathrm{ml}$ also increased the level of viable melanoma cells in the group (visfatin $+\mathrm{H}_{2} \mathrm{O}_{2}$ ) along with a decreased level of DNA damage when compared to cells treated solely with $\mathrm{H}_{2} \mathrm{O}_{2}$.

We also examined the effect of visfatin on Me45 melanoma cell proliferation. Previous studies reported that visfatin stimulates proliferation of osteoblasts (39), vascular smooth muscle cells (VSMC) (38) and prostate cancer cells (PC-3 line) (21). The present study demonstrated that visfatin $(10-100 \mathrm{ng} / \mathrm{ml})$, similar to insulin, stimulates proliferation of Me45 cells in vitro in a dose-dependent manner. Patel et al (21) also reported that visfatin $(25-400 \mathrm{ng} / \mathrm{ml})$ increases proliferation of the $\mathrm{PC}-3$ prostate cancer cell line in a dose-dependent manner after $24 \mathrm{~h}$ of incubation. The most pronounced proliferation rate increase (approximately 2-fold) was observed in the PC-3 cells subjected to visfatin at the concentration of $400 \mathrm{ng} / \mathrm{ml}$. In the present study, an almost 2-fold increase of the proliferation rate was observed in Me45 cells treated with $100 \mathrm{ng} / \mathrm{ml}$ visfatin with increased number of tumor viable cells. The supraphysiological concentration of visfatin in culture medium was similar to the concentrations used in other in vitro studies $(6,7,13,17,21,38,39)$. These observation are concordant with a report which shows that increased GSH-Px or CAT activity enables cells to survive with the high level of ROS and maintain cellular viability (36). By contrast, in this case, high concentration of visfatin $(250 \mathrm{ng} / \mathrm{ml})$ led to a significant decrease of $\left[{ }^{3} \mathrm{H}\right]$ thymidine incorporation of Me45 cells with respect to the untreated cells. The effect on proliferation was demonstrated in a concentration-dependent manner and perhaps more importantly at levels of visfatin similar to those that have been demonstrated in obese patients (40). This provides novel evidence that elevated levels of circulating visfatin may influence the growth of melanoma cancer cells. According to other research studies, visfatin can mimic the effects of insulin on the activation of insulin signaling $(17,39)$. In particular, two studies in monocytes and in osteoblasts have indicated that IR may be involved in visfatin function; both studies demonstrated that visfatin effects could be blocked by IR tyrosine kinase inhibitor, HNMPA- $(\mathrm{AM})_{3}(13,39)$. However, recent studies indicated that visfatin cannot activate IR (41) and proposed that visfatin may act on its own unidentified receptor (42). Therefore, to determine whether visfatin-induced Me45 melanoma cell proliferation is mediated by IR, we used HNMPA-(AM) $)_{3}$ - inhibitor of IR to elucidate this matter, with insulin as a comparison. In our study melanoma cultures pretreated with visfatin and the IR tyrosine kinase inhibitor HNMPA-(AM) $)_{3}$ acted similarly to cells cultured in the absence of the latter. These observations indicated that visfatin-induced melanoma cell proliferation is not mediated by the IR transduction signaling pathway. We also demonstrated that the HNMPA-(AM $)_{3}$ significantly inhibited insulin-stimulated proliferation of melanoma Me45 cells.

Our study has a few limitations. Its in vitro setting may not fully reflect more complex relationships in organisms as a whole. Additionally, we observed an increased proliferation rate occurring during cell culture. However the magnitude of proliferation was relatively much lower than the effect of visfatin on studied parameters, therefore we considered the influence of this observation as negligible in the study results.

In conclusion, this study provides the first evidence that visfatin can reduce the level of DNA damage of Me45 melanoma cells, probably due to increased levels of antioxidative enzyme activities, and can promote melanoma cell proliferation in a dose-dependent manner.

\section{Acknowledgements}

This study was supported by grants from the Silesian Medical University in Katowice, Poland. Grant nos. KNW-1-134/08, KNW-1-078/09 and KNW-1-040/P/1/0.

\section{References}

1. Tilg $\mathrm{H}$ and Moschen AR: Role of adiponectin and PBEF/visfatin as regulators of inflammation: involvement in obesity-associated diseases. Clin Sci 114: 275-288, 2008.

2. Cappellani A, Di Vita M, Zanghi A, Cavallaro A, Piccolo G, Veroux M, Berretta M, Malaguarnera M, Canzonieri V and Lo Menzo E: Diet, obesity and breast cancer: an update. Front Biosci (Schol Ed) 4: 90-108, 2012.

3. Thomas CC, Wingo PA, Dolan MS, Lee NC and Richardson LC: Endometrial cancer risk among younger, overweight women. Obstet Gynecol 114: 22-27, 2009.

4. Larsson SC and Wolk A: Overweight, obesity and risk of liver cancer: a meta-analysis of cohort studies. Br J Cancer 97: 1005-1008, 2007.

5. Dennis LK, Lowe JB, Lynch CF and Alavanja MC: Cutaneous melanoma and obesity in the Agricultural Health Study. Ann Epidemiol 18: 214-221, 2008.

6. Oita RC, Ferdinando D, Wilson S, Bunce C and Mazzatti DJ: Visfatin induces oxidative stress in differentiated $\mathrm{C} 2 \mathrm{C} 12$ myotubes in an Akt- and MAPK-independent, NFkB-dependent manner. Pflugers Arch 459: 619-630, 2010.

7. Adya R, Tan BK, Punn A, Chen J and Randeva HS: Visfatin induces human endothelial VEGF and MMP-2/9 production via MAPK and PI3K/Akt signalling pathways: novel insights into visfatin-induced angiogenesis. Cardiovasc Res 78: 356-365, 2008.

8. Berndt J, Klöting N, Kralisch S, Kovacs P, Fasshauer M, Schön MR, Stumvoll M and Blüher M: Plasma visfatin concentrations and fat depot-specific mRNA expression in humans. Diabetes 54: 2911-2916, 2005.

9. Tanaka M,Nozaki M,Fukuhara A,Segawa K, Aoki N, Matsuda M, Komuro R and Shimomura I: Visfatin is released from 3T3-L1 adipocytes via a non-classical pathway. Biochem Biophys Res Commun 359: 194-201, 2007. 
10. Garten A, Petzold S, Barnikol-Oettler A, Körner A, Thasler WE Kratzsch J, Kiess W and Gebhardt R: Nicotinamide phosphoribosyltransferase (NAMPT/PBEF/visfatin) is constitutively released from human hepatocytes. Biochem Biophys Res Commun 391: $376-381,2010$.

11. Friebe D, Neef M, Kratzsch J, Erbs S, Dittrich K, Garten A, Petzold-Quinque S, Blüher S, Reinehr T, Stumvoll M, Blüher M, Kiess W and Körner A: Leucocytes are a major source of circulating nicotinamide phosphoribosyltransferase (NAMPT)/pre-B cell colony (PBEF)/visfatin linking obesity and inflammation in humans. Diabetologia 12: 1200-1211, 2011.

12. Laudes M, Oberhauser F, Schulte DM, Freude S, Bilkovski R, Mauer J, Rappl G, Abken H, Hahn M, Schulz O and Krone W: Visfatin/PBEF/Nampt and resistin expressions in circulating blood monocytes are differentially related to obesity and type 2 diabetes in humans. Horm Metab Res 42: 268-273, 2010.

13. Dahl TB, Yndestad A, Skjelland M, Øie E, Dahl A, Michelsen A, Damås JK, Tunheim SH, Ueland T, Smith C, Bendz B, Tonstad S, Gullestad L, Frøland SS, Krohg-Sørensen K, Russell D, Aukrust P and Halvorsen B: Increased expression of visfatin in macrophages of human unstable carotid and coronary atherosclerosis: possible role in inflammation and plaque destabilization. Circulation 115: 972-980, 2007.

14. Sommer G, Garten A, Petzold S, Beck-Sickinger AG, Blüher M, Stumvoll M and Fasshauer M: Visfatin/PBEF/Nampt: structure, regulation and potential function of a novel adipokine. Clin Sci 115: 13-23, 2008.

15. Dahl TB, Holm S, Aukrust P and Halvorsen B: Visfatin/NAMPT: a multifaceted molecule with diverse roles in physiology and pathophysiology. Annu Rev Nutr 32: 229-243, 2012.

16. Moschen AR, Kaser A, Enrich B, Mosheimer B, Theurl M, Niederegger $\mathrm{H}$ and Tilg $\mathrm{H}$ : Visfatin, an adipocytokine with proinflammatory and immunomodulating properties. J Immunol 178 : 1748-1758, 2007.

17. Fukuhara A, Matsuda M, Nishizawa M, Segawa K, Tanaka M, Kishimoto K, Matsuki Y, Murakami M, Ichisaka T, Murakami H, Watanabe E, Takagi T, Akiyoshi M, Ohtsubo T, Kihara S, Yamashita S, Makishima M, Funahashi T, Yamanaka S, Hiramatsu R, Matsuzawa Y and Shimomura I: Visfatin: a protein secreted by visceral fat that mimics the effects of insulin. Science 307: 426-430, 2005

18. Imai S: Nicotinamide phosphoribosyltransferase (Nampt): a link between NAD biology, metabolism, and diseases. Curr Pharm Des 15: 20-28, 2009.

19. Shackelford RE, Bui MM, Coppola D and Hakam A: Overexpression of nicotinamide phosphoribosyltransferase in ovarian cancers. Int J Clin Exp Pathol 3: 522-527, 2010.

20. Reddy PS, Umesh S, Thota B, Tandon A, Pandey P, Hegde AS, Balasubramaniam A, Chandramouli BA, Santosh V, Rao MR, Kondaiah P and Somasundaram K: PBEF1/NAmPRTase/Visfatin: a potential malignant astrocytoma/glioblastoma serum marker with prognostic value. Cancer Biol Ther 7: 663-668, 2008.

21. Patel ST, Mistry T, Brown JE, Digby JE, Adya R, Desai KM and Randeva HS: A novel role for the adipokine visfatin/pre-B cell colony-enhancing factor 1 in prostate carcinogenesis. Peptides 31: 51-57, 2010.

22. Park SH, Ozden O, Jiang H, Cha YI, Pennington JD, AykinBurns N, Spitz DR, Gius D and Kim HS: Sirt3, mitochondrial ROS, ageing, and carcinogenesis. Int J Mol Sci 12: 6226-6239, 2011.

23. Kong W, Kuester RK, Gallegos A and Sipes IG: Induction of DNA damage in human urothelial cells by the brominated flame retardant 2,2-bis(bromomethyl)-1,3-propanediol: role of oxidative stress. Toxicology 290: 271-277, 2011.

24. Angeli JP, Garcia CC, Sena F, Freitas FP, Miyamoto S, Medeiros MH and Di Mascio P: Lipid hydroperoxide-induced and hemoglobin-enhanced oxidative damage to colon cancer cells. Free Radic Biol Med 51: 503-515, 2011.
25. Hegde ML, Hazra TK and Mitra S: Early steps in the DNA base excision/single-strand interruption repair pathway in mammalian cells. Cell Res 18: 27-47, 2008

26. Trachootham D, Alexandre J and Huang P: Targeting cancer cells by ROS-mediated mechanisms: a radical therapeutic approach? Nat Rev Drug Discov 8: 579-591, 2009.

27. Kramer-Marek G, Serpa C, Szurko A, Widel M, Sochanik A, Snietura M, Kus P, Nunes RM, Arnaut LG and Ratuszna A: Spectroscopic properties and photodynamic effects of new lipophilic porphyrin derivatives: efficacy, localisation and cell death pathways. J Photochem Photobiol B 84: 1-14, 2006.

28. Paglia DE and Valentine WN: Studies on the quantitative and qualitative characterization of erythrocyte glutathione peroxidase. J Lab Clin Med 70: 158-169, 1967.

29. Paoletti F and Mocali A: Determination of superoxide dismutase activity by purely chemical system based on NAD $(\mathrm{P}) \mathrm{H}$ oxidation. Methods Enzymol 186: 209-220, 1990.

30. Aebi H: Catalase in vitro. Methods Enzymol 105: 121-126, 1984

31. Placer ZA, Cushman LL and Johnson BC: Estimation of product of lipid peroxidation (malonyl dialdehyde) in biochemical systems. Anal Biochem 16: 359-364, 1966.

32. Olive PL and Banáth JP: Detection of DNA double-strand breaks through the cell cycle after exposure to X-rays, bleomycin, etoposide and ${ }^{125}$ IdUrd. Int J Radiat Biol 64: 349-356, 1993.

33. Turrens JF: Mitochondrial formation of reactive oxygen species. J Physiol 552: 335-344, 2003.

34. Polaniak R, Bułdak RJ, Karoń M, Birkner K, Kukla M, ZwirskaKorczala K and Birkner E: Influence of an extremely low frequency magnetic field (ELF-EMF) on antioxidative vitamin E properties in AT478 murine squamous cell carcinoma culture in vitro. Int J Toxicol 29: 221-230, 2010.

35. Samuels BL, Murray JL, Cohen MB, Safa AR, Sinha BK, Townsend AJ, Beckett MA and Weichselbaum RR: Increased glutathione peroxidase activity in a human sarcoma cell line with inherent doxorubicin resistance. Cancer Res 51: 521-527, 1991.

36. Lenehan PF, Gutiérrez PL Wagner JL, Milak N, Fisher GR and Ross DD: Resistance to oxidants associated with elevated catalase activity in HL-60 leukemia cells that overexpress multidrug-resistance protein does not contribute to the resistance to daunorubicin manifested by these cells. Cancer Chemother Pharmacol 35: 377-386, 1995.

37. Gaweł S, Wardas M,Niedworok Eand Wardas P: Malondialdehyde (MDA) as a lipid peroxidation marker Wiad Lek 57: 453-455, 2004.

38. Wang P, Xu TY, Guan YF, Su DF, Fan GR and Miao CY: Perivascular adipose tissue-derived visfatin is a vascular smooth muscle cell growth factor: role of nicotinamide mononucleotide. Cardiovasc Res 81: 370-380, 2009.

39. Xie H, Tang SY, Luo XH, Huang J, Cui RR, Yuan LQ, Zhou HD, Wu XP and Liao EY: Insulin-like effects of visfatin on human osteoblasts. Calcif Tissue Int 80: 201-210, 2007.

40. Haider DG, Schindler K, Schaller G, Prager G, Wolzt M and Ludvik B: Increased plasma visfatin concentrations in morbidly obese subjects are reduced after gastric banding. J Clin Endocrinol Metab 91: 1578-1581, 2006.

41. Revollo JR, Körner A, Mills KF, Satoh A, Wang T, Garten A, Dasgupta B, Sasaki Y, Wolberger C, Townsend RR, Milbrandt J, Kiess W and Imai S: Nampt/PBEF/Visfatin regulates insulin secretion in beta cells as a systemic NAD biosynthetic enzyme. Cell Metab 6: 363-375, 2007.

42. Kim SR, Bae YH, Bae SK, Choi KS, Yoon KH and Koo TH: Visfatin enhances ICAM-1 and VCAM-1 expression through ROS-dependent NF-kappaB activation in endothelial cells. Biochim Biophys Acta 1783: 886-895, 2008. 